\title{
The relation between economics and theology in Caritas in Veritate
}

\author{
A. M. C. WATERMAN \\ University of Manitoba \\ St John's College, Winnipeg
}

\begin{abstract}
Caritas in Veritate is the latest in the series of papal 'social encyclicals' beginning with Rerum Novarum (1891). Like its immediate predecessor Centesimus Annus (1991), it presents a body of economic doctrine favourable to the market economy that is superimposed on an underlying body of older doctrine that is deeply hostile to it. This article investigates the possibility that this incoherence results from a corresponding incoherence in the theological framework of the recent encyclicals. The doctrine of the encyclicals is then contrasted with an eighteenth-century, Anglo-Scotch tradition of thought that showed the compatibility with Catholic moral theology of a privately owned, competitive economy driven by self-love. This tradition is the intellectual origin of modern economics, yet it has not been available to the Church of Rome because of an historical accident. The article concludes by speculating upon the reasons for this.
\end{abstract}

Keywords: history of economics, moral theology, political economy, social policy, economic development, self-love

JEL Classification: B19, B29, H10, I30, O10, O20

Caritas in Veritate ( $\mathrm{CV}$ ) of Pope Benedict XVI, published in June 2009, was the latest in a series of 'social encyclicals' that begins with Rerum Novarum $(R N)$ of Leo XIII, issued in 1891. As Quadragesimo Anno (QA) of Pius XI was intended to celebrate the fortieth anniversary of $R N$, so $C V$ looks back to Populorum Progressio (PP) issued by Paul VI in 1967 $(C V, 10)$. Though papal social doctrine has often been promulgated through other documents, the series of social encyclicals from $R N$ to $C V$ epitomizes that doctrine, and enables us to mark change and

AUTHOR'S NoTE: Earlier versions of this article were presented at a Catholic Studies conference in St Thomas More College, University of Saskatchewan in March 2011, and at a public lecture in Regent College, University of British Columbia in June 2011. The author is grateful for helpful comments from Paul Oslington, Gary Hewitt, and other participants on each occasion. 
development since 1891. In what follows, I shall first analyse the treatment of economic matters, with special attention to Centesimus Annus (CA) and $C V$, showing that there is-or has been since 1991-a serious internal contradiction. A body of doctrine favourable to the market economy is superimposed on an underlying body of older doctrine that is deeply hostile to it. Next I shall explore the possibility that this incoherence results from a corresponding incoherence in the theological framework of the recent encyclicals. In the third section I report the achievement of Anglican thinkers in the eighteenth century, building on the French Jansenist theodicy of the previous century, in showing the compatibility of (Catholic) moral theology with a privately owned, competitive economy driven by self-love. But because of an historical accident this solution has not been available to the Church of Rome. In a final section I speculate on the reasons for this.

\section{ECONOMIC IDEAS IN CARITAS IN VERITATE}

The encyclical recognises explicitly several fundamentally important ideas, acknowledged by economists to be necessary conditions of sustained development and growth. These are 'social capital', human capital, the internalization of environmental costs, the rule of law, and individual initiative.

By 'social capital' is meant "the network of relationships of trust, dependability, and respect for rules, all of which are indispensable for any form of civil coexistence" $(C V, 32)$. And indeed "without internal forms of solidarity and trust, the market cannot completely fulfil its proper economic function" ( $C V, 35)$; i.e., "The economy needs ethics in order to function effectively" ( $C V, 45$; all italics are from the original unless otherwise stated) a position which closely resembles what I have elsewhere called the 'Folbre-Morse thesis' (see Waterman 2003b). These undeniable propositions-sometimes forgotten or neglected by present-day economists-are associated with more controversial yet arguable claims: social capital is weakened or eroded by the "systemic increase of social inequality" $(C V, 32)$, therefore the market requires not only commutative justice but also distributive justice $(C V, 35)$.

The importance of human capital is clearly acknowledged: the "primary capital to be safeguarded and valued is man, the human person in his or her integrity" ( $C V, 25)$, wherefore "the most valuable resources in countries receiving development aid are human resources; herein lies the real capital that needs to accumulate in order to guarantee a truly 
autonomous future for the poorest countries" ( $C V, 58)$. Economists might substitute "all" for "the poorest" and be sceptical about "a truly autonomous future" for any country in today's world, but all would agree that human capital is the fundamental economic resource.

The encyclical touches on the problem of environmental degradation resulting from economic growth, and correctly maintains that "the economic and social cost of using up shared environmental resources" be "recognized with transparency and fully borne by those who incur them" $(C V, 50)$. Noting that some adverse economic effects of growth are "the result of impoverishment and underdevelopment", it points out that "When incentives are offered for their economic and cultural development, nature itself is protected" $(C V, 51)$.

Aid to developing countries should include "reinforcing the guarantees proper to the state of law: a system of public order [...]" $(C V, 41)$, which appears to mean what is more usually known as the 'rule of law'-and which has been understood at least since the eighteenth century to be a necessary condition of a viable economy under any possible assignment of ownership rights. Thus "corruption and illegality" in both rich and poor countries $(C V, 22)$ impairs development. Some problems of third-world economies are selfinflicted, and caused by "political irresponsibility" $(C V, 26)$, indeed "grave irresponsibility within the very countries that have achieved independence" $(C V, 33)$.

In addition to the observations about incentives and the rule of law, there is some slightly more explicit awareness that economic activity is driven by individuals: "The peoples themselves have the prime responsibility to work for their own development" ( $C V$, 47; citing $P P, 77)$. This necessary self-reliance can be undermined by foreign and domestic paternalism:

At times $[\ldots]$ those who receive aid become subordinate to the aidgivers, and the poor serve to perpetuate expensive bureaucracies which consume an excessively high percentage of the funds intended for development $(C V, 47)$.

These true and important insights imply that economic activity is driven by purposeful individuals and firms, dependent upon publicly sanctioned and privately ratified law and order, having self-determined goals and therefore responsive to incentives. They are also consistent with the assumption that agents in the public sector are motivated in 
the same way, by their own private goals. Yet they coexist with many passages in $C V$ which appear to deny that individuals "motivated by purely selfish ends" $(C V, 36)$ can produce socially beneficent outcomes as unintended consequences, and which rest instead on a naïve reliance upon the wisdom and goodness of public functionaries. The underlying assumptions of these dissonant doctrines are what I shall call organicism and constructivism.

By 'organicism' I mean a conception of human society as a living body, necessarily governed by a 'head' which all other 'members' must obey if it is to remain viable. I have analysed the centrality of organicism for papal social teaching in previous work (Waterman 1999) and shall return to it below. Its most obvious signs in $C V$ are the continual hypostatizing of such abstractions as "nations", "the political community", and "the international community"; its frequent references to human "solidarity" $(C V, 19,21,25,38,39,43,44,54,58)$; and its authors' desire for "a true world political authority", with "authority to ensure compliance", which would "manage the global economy" and "seek to establish the common good" $(C V, 67)$.

'Constructivism' is a term coined by F. A. Hayek to denote the assumption "that we have it in our power so to shape our institutions that of all possible sets of results that which we prefer to all others will be realized" (Hayek 1967, 85). Hence the recollection in CV of JohnPaul II's call in 1991 for "a comprehensive new plan for development" not only in Eastern Europe "but also in the West and in those parts of the world that were in the process of evolving" ( $C V, 22-29)$. Benedict XVI speaks of "constructing [sic] a new order of economic productivity" $(C V, 41)$; of the need to "replan our journey" $(C V, 21)$ and for "comprehensive new plans for development" $(C V, 23)$; and contemplates a "reason" that is capable of "knowing and directing" globalization $(C V, 33)$ so as to achieve "distributive justice and social justice for the market economy" $(C V, 35)$. It is evident that the drafting committees and authors of these encyclicals envisage a world in which those in political authority might have the knowledge and the power not merely to affect but actually to determine the structure and operation of the economy; and have the wisdom and goodness to do so in a way that may achieve the common good.

These assumptions were common among economic thinkers at one time, especially in the seventeenth century when économie politique emerged as a set of recipes for running France as the manorial fief of 
le roi soleil. But since the early eighteenth century increasing scepticism about the four attributes, particularly those of knowledge and goodness, has gradually led economists to a very different view of the world. The key figure is David Hume (1711-1776), whose radical scepticism about the possibility of human knowledge-inspired perhaps by Joseph Butler (1692-1752), Bishop of Durham-brought him and his successors in the so-called 'Scottish Enlightenment' to see that

every step and every movement of the multitude, even in what are termed enlightened ages, are made with equal blindness to the future; and nations stumble upon establishments, which are indeed the result of human action, but not the execution of any human design (Ferguson 1767, 187).

David Hume, Adam Ferguson (1723-1816), Adam Smith (1723-1790), and John Millar (1735-1801) came to see human societies not as bodies-and certainly not as machines, as some socialist theory later implied-but rather as quasi-biological habitats, in which what John Stuart Mill (1874) later called a "spontaneous order of nature" emerges as the unintended outcome of a myriad of private, selfregarding acts by individuals. In market economies individual, self-regarding transactions are coordinated by prices for goods and services. When there is enough competition, an 'invisible hand' will produce the optimum pattern of production and consumption, given any initial distribution of assets.

If economic activity is driven by the self-regarding acts of individuals, we must abandon the assumption that political decisionmakers are better than the rest of us. A business executive does not become altruistic merely by accepting a job in government. There is no reason to expect that ministers and civil servants will be any less self-interested than business managers and trade union officials; nor any reason to suppose that managers will subordinate their own private interests to those of their shareholders or union bosses to those of their rank-and-file (see $C V, 25$ ).

In the view of economists therefore, papal confidence in beneficent, 'top-down' governance is misplaced on two counts. First, 'the sovereign' must not be charged with

a duty, in the attempting to perform which he must always be exposed to innumerable delusions, and for the proper performance of which no human wisdom or knowledge could ever be sufficient; 
the duty of superintending the industry of private people, and of directing it towards the employments most suitable to the interest of the society (Smith [1776] 1976, 687).

Secondly,

that, in contriving any system of government and fixing the several checks and controuls of the constitution, every man ought to be supposed a knave and to have no other end, in all his actions, than private interest (Hume [1752] 1994, 21).

Whether this radically different view of society is more or less accurate than the organicism and constructivism of papal social teaching is of secondary importance. What matters here is that the latter is fundamentally incompatible with what economists would accept as the valid insights of $C V$. For if 'the market' actually works at all, which the encyclical certainly assumes it does (e.g., $C V, 25$ ), it does so because economic activity arises from the private acts of individuals "motivated by purely selfish ends" $(C V, 36)$, responding to incentives $(C V, 51)$, and with a productivity augmented by their human capital $(C V, 58)$. The duties of "the sovereign" (i.e., the government of a sovereign state) are thus confined to national defence, the provision of public goods, education $(C V, 61)$, and the maintenance of the rule of law $(C V, 41$; see Smith [1776] 1976, V.i). This conception of the economy contradicts the idea of any "comprehensive new plans for development" $(C V, 23)$ or of a human "reason" that is capable of "knowing and directing" globalization $(C V, 33)$; and vice versa.

It is noteworthy that in its correct insistence on the overriding necessity of "the network of relationships of trust, dependability, and respect for rules" $(C V, 32)$ the encyclical seems implicitly to recognize the fact that individuals, both in the private and the public sector, are normally motivated by self-interest; and that it is this that actually drives all economic activity. Now unless the self-seeking propensities of individuals in each sector are disciplined by individually internalized ethical imperatives-unless most people normally obey the rules of the game even when the referee is not looking-the market game quickly ceases to be worth playing, and society descends into the Hobbesian anarchy of a Somalia or a Côte d'Ivoire. Which is why "The economy needs ethics in order to function effectively" $(C V, 45)$. 


\section{SOME THEOLOGICAL ELEMENTS OF CARITAS IN VERITATE}

It is not reasonable to expect that this encyclical should contain a complete theological rationale of its doctrine since it is explicitly one in the series of 'social encyclicals' and continually cites the authority of its predecessors. Yet it may be useful to identify some of the more important theological themes in $C V$ as a preliminary to the discussion in part III. These are Caritas, the Holy Trinity, the unity of the human race, Nature, the prophetical mission of the Catholic Church, original sin, and Providence.

Caritas, which signifies more than 'charity' or 'love' in ordinary English usage, is that $\alpha \gamma \alpha \pi \eta$ identified by St Paul (I Cor 13:1-4) as a necessary condition of the Christian life. It is known by Christ's giving of himself for the redemption of the world (I John 4:7-12), for "God is love" ('o $\Theta \varepsilon o s \alpha \gamma \alpha \pi \eta \varepsilon \sigma \tau \imath v$, I John 4:8). Thus the encyclical can affirm that "everything is shaped by it" $(C V, 2)$. Caritas is therefore "an element of fundamental importance in human relations, including those of a public nature" $(C V, 3)$. Combined with Truth (Veritas), Caritas "shows us the way to true development" $(C V, 52)$.

The doctrine of the Holy Trinity, described as a "revealed mystery", is invoked in Caritas in Veritate $(C V, 54)$ to illustrate the hypereconomic, transcendent conception of "development" proposed by $P P$ and $C V$. This conception "can be identified with the inclusion-in-relation of all individuals and peoples within the one community of the human family, built in solidarity [...]" The Trinity-in-Unity shows that for human beings too "true openness does not mean loss of individual identity but profound interpenetration", hence God desires (John 17:22) "that they may be one even as we are one" $(C V, 54)$. Therefore "The Christian revelation of the unity of the human race" $(C V, 55)$ "does not submerge the identities of individuals, peoples and cultures, but [...] links them more closely in their legitimate diversity" $(C V, 53)$.

Nature "is a gift of the Creator who has given it an inbuilt order". It "speaks to us of the Creator" and "expresses a design of truth and love" since it is "not the result of mere chance or evolutionary determinism" ( $C V, 48)$. It might appear from this that the encyclical asserts the traditional, pre-Darwinian view of the 'book of Nature', which we may read, as did Sir Isaac Newton and Archdeacon William Paley, to discover evidence of the design of the universe by an all-knowing, all powerful, all-wise and all-good Deity. However it is possible (though they do not tell us) that the authors believe they have defensible 
philosophical grounds for accepting organic evolution as a useful scientific theory on the one hand, without having to abandon teleology on the other. 'Nature' and its cognates are often used narrowly and loosely in $C V$ to mean nothing more than the human environment (e.g., $C V, 48,49,50,51$ ); and at one point it is asserted that there is "a covenant between human beings and their environment" $(C V, 69)$. But it is also used metaphysically: because we are made in the image of God we may discover "the inviolable dignity of the human person and the transcendent value of natural moral norms" $(C V, 45)$. For in

all cultures there are examples of ethical convergence, some isolated, some interrelated, as an expression of the one human nature, willed by the Creator; the tradition of ethical wisdom knows this as the natural law. This universal moral law provides a sound basis for all cultural, religious and political dialogue $(C V, 59)$.

It also provides a basis for the populationist, anti-birth-control doctrine of Humanae Vitae $(H V, 4)$ issued by Paul VI in 1968, and reasserted by Benedict as "highly important for delineating the fully human meaning of the development that the Church proposes" $(C V, 15)$.

Echoing Quadragesimo Anno (QA, 41), this encyclical acknowledges that "The Church does not have technical solutions to offer" and does not claim to "interfere in any way in the politics of States" ( $C V, 9$; quoting $P P, 13)$. But

She does, however, have a mission of truth to accomplish, in every time and circumstance, for a society that is attuned to man, to his dignity, to his vocation [...] For this reason the Church searches for the truth, proclaims it tirelessly, and recognizes it when it is manifested $(C V, 9)$.

Upon the assumption, which virtually every Christian would accept, that the Church will be led by the Holy Spirit into all truth (John 16:13) - recognizing that 'truth' in this sense is spiritual and theological, not scientific-the Church has both the right and the duty to proclaim to the whole world those divinely revealed facts about human existence which must govern private and public morality if humans are to flourish. As a twentieth-century Archbishop of Canterbury once put it in a homely example, he might have to say to the Prime Minister:

No; I cannot tell you what is the remedy; but I can tell you that a society of which unemployment [...] is a chronic feature is a diseased 
society, and that if you are not doing all you can to find and administer a remedy, you are guilty before God (Temple [1942] 1976, 45).

The Church thus has a prophetical office. Like the prophets of ancient Israel, those who speak in her name must sometimes declare unpalatable truths to the rest of society.

A vitally important passage in Centesimus Annus warned us of "the wound of original sin" and of its consequences for social order:

Man tends towards good, but he is also capable of evil. He can transcend his immediate interest and still remain bound to it. The social order will be all the more stable, the more it takes this fact into account and does not place in opposition personal interest and the interests of society as a whole, but rather seeks ways to bring them into fruitful harmony. In fact, where self-interest is violently suppressed, it is replaced by a burdensome system of bureaucratic control which dries up the wellsprings of initiative and creativity (CA, 25; italics added).

This passage is alluded to in Caritas in Veritate ( $C V, 34$, note 85 ) but, unlike in $C A$, no inferences whatsoever are drawn from "the presence of original sin in social conditions" $(C V, 34)$ for any need to allow "personal interest" to operate for the benefit of "the interest of society as a whole". If anything, the paragraph in $C V$ seems to tend in the opposite direction. (I shall return to this topic in detail below.)

A key element in the theological analysis of the place of original sin in social and economic affairs is the idea of Divine Providence. It is mentioned once, briefly, in this encyclical: "development requires [...] reliance on God's providence and mercy" $(C V, 79)$. But the concept does no work in that context and is merely decorative. (It too will be studied more carefully in part III.)

Each of these theological elements is important, and three of themCaritas, original sin, and the Holy Trinity-lie at the heart of Christian orthodoxy. But as employed in Centesimus Annus and Caritas in Veritate, especially the latter, they are left undeveloped. There is no theological rationale of self-interest and spontaneous order which would validate those passages which appear to recognise the efficacy of competitive market institutions, and which would deliver Papal social teaching from its reliance on the 'Romantic categories' (Waterman 2003a) of organicism and constructivism. Why should this be? 
Part of the answer may lie in the fact that the idea of original sin, as developed authoritatively from biblical and earlier patristic sources by St Augustine (who seems to have coined the term), may be in conflict with other themes that $C V$ wishes to assert, such as "the fundamental values of justice and peace" required for human solidarity $(C V, 54)$. For Augustine taught that, because of sin, true justice (vera justitia) is impossible in this life; and that no state can exist without positive injustice (Deane 1963, 118-126; citing many scattered examples from Augustine's unsystematic writings). And because sin has destroyed the fraternity natural to human society, no true peace is possible in this Earthly City (Terrena Civitas), only the absence of overt conflict that a state having a monopoly of coercion can forcibly impose (Deane 1963, 95-100). It seems clear that for Augustine human solidarity can only be realized in the City of God (Civitas Dei), and is not to be looked for in any conceivable this-worldly set of political arrangements.

There is therefore a fundamental theological dissonance in Papal social teaching, which corresponds to some extent with the contradictory economic ideas identified in Part I above.

The Christian organicism that runs through the social encyclicals like a leit-motif conceives of human society in terms borrowed from the Pauline doctrine of the Church as the mystical body of Christ, as the "body politic" or "body social". In Quadragesimo Anno, for example, the faithful are taught that "it will be possible to say in a sense even of this body what the Apostle says of the mystical body of Christ: 'The whole body (being closely joined and knit together...) derives its increase to the building up of itself in love'" $(Q A, 90)$. It is in this sense that $C V$ can affirm that Caritas "is at the heart of the Church's social doctrine $(C V, 2)$, reflecting a commonplace of sixteenth-century political thought: that love is the cement that holds society together.

[...] yf al the partys of the cyty wyth love be not knyt togyddur in unyte as membres of one body, ther can be no cyvylyte [...] [but] [...] there ys perfayt cyvylyte [...] where [...] al the partys [...] be knyt togyddur in perfayt love \& unyte, evey one dowying hys offyce \& duty [...] \& wythout envy or malyce to other accomplysh the same [...] (Starkey [1538] 1989, 37).

Because of an accident of history (Waterman 2004, chapters 11 and 12), that social doctrine was shaped at its outset by Leo XIII's commitment to Thomistic philosophy, promulgated in Aeterni Patris (1879). In 1888, three years before $R N$, Leo issued the encyclical Libertas 
Praestantissimus which mounted a frontal assault on nineteenth-century liberalism: the sovereignty of the people, democracy, and the so-called "liberties" of religion, speech, the press, and teaching ( $L P, 15-25)$. According to the Thomistic apparatus of that encyclical:

The eternal law of God is the sole standard and rule of human liberty, not only in each individual man, but also in the community and society which men constitute when united. Therefore the true liberty of human society does not consist in every man's doing as he pleases, for this would simply end in turmoil and confusion and bring on the overthrow of the State $[\ldots](L P, 10)$.

There is no possibility in this theological framework of accommodating the idea that individuals might bring about a socially benign state of affairs as the unintended consequence of pursuing their own private ends. The Body must be held together by love; and all its members must obey the eternal law of God.

Original sin throws all this into doubt. Because of sin, love often fails; and because of sin we continually disobey the eternal laws of God. Yet-save in exceptional and temporary circumstances such as those now prevailing in some Arab dictatorships-we do not normally see "turmoil and confusion". Indeed it is precisely in those places where individuals have been freest to pursue their own private ends, notably in Britain, the USA and other English-speaking countries, that we see the highest achievements of peaceable cooperation.

Evidently there is theological work for Providence to perform. St Augustine confronted the problem of evil presented by his horrifying doctrine of original $\sin$ with a theodicy of social and political institutions. God is just and allows us to suffer the consequences of original sin. But He is also merciful and provides means for those very consequences themselves to become remedies for our sin. The state, private property, slavery, and the hangman are evil in themselves, but under Divine Providence they save us from a worse evil: destruction by our more powerful neighbours at home and abroad (Deane 1963, chapters III, IV passim).

\section{THEODICY, APOLOGETIC, AND THE MARKET ECONOMY}

Late seventeenth-century Jansenist scholars proposed an Augustinian theodicy of self-interest in economic life using the concepts of original sin and Providence. Anglican thinkers in the eighteenth century provided 
an Apologetic of self-interest by developing the concept of Caritas. Those we now think of anachronistically as 'economists' in France and Britain made use of their work to assemble a coherent, large-scale theory of the self-regulating market economy that was acceptable to the most rigorous religious and moral sensibilities in a Christian society.

The internationally celebrated moralist Pierre Nicole (1625-1695) and the eminent jurist Jean Domat (1625-1696) taught at the Benedictine community of Port Royal. This was the home of the so-called 'Jansenist' movement within the Gallican Church, which was more purely Augustinian-less Thomistic-than was usual among Roman Catholics at that time. Acutely conscious of the pervasiveness of human sin, Nicole and Domat were forced to construct a theodicy of civil life for their students. Why does God allow humans, created in his own image but defaced by original sin, to be as selfish, power-hungry, predatory, and cruel as we continually observe our species to be? Their solution followed St Augustine's model. Under Providence the unintended consequences of our self-seeking propensities include the bringing about of the institutions of political society, which are both a punishment and a remedy for sin. Nicole and Domat extended the analysis to the market economy.

[...] when travelling [...] we find men ready to serve those who pass by and who have lodgings to receive them almost everywhere. We dispose of their services as we wish. We command them; they obey [...] What could be more admirable than these people if they were acting from charity? It is cupidity which induces them to act [...] Think what charity would be required to build an entire house for another man, furnish it, carpet it and hand him the key. Cupidity does this quite joyfully (Nicole 1670, 204-205; cited in Faccarello 1999, 28).

For Augustine 'cupidity' or 'avarice' is one of the three primary sources of 'lust' (libido), "the fundamental quality of the unregenerate" (Deane 1963, 44). Yet in this context it is conceived as permitted, even as used, by God to compensate for a failure of Caritas.

Gilbert Faccarello (1999, 26-32) cites a range of cognate passages from both Nicole and Domat to illustrate the general Augustinian position summarized by Domat:

[...] from so evil a passion as our self-love, and from a poison so contrary to the mutual love which ought to be the foundation of 
society, God created one of the remedies which enable it to survive; for from the principle of division He constructed a link which unites all men in a thousand ways and which maintains most agreements (Domat [1689] 1828-1829, 25; cited in Faccarello 1999, 27).

Faccarello has shown how the French economic thinker, Pierre de Boisguilbert (1646-1714), who had been a pupil at Port Royal under Nicole and Domat, constructed the first complete theory of the selfregulating market economy on this basis. His Le détail de la France ([1695] 1966, vol. 2, 591-661) explained how, under Providence, the unintended consequences of the competition of agents, each motivated by self-love in response to incentives created by market prices, produced a state of "harmony" or "equilibrium". Modern economic theory, descending from Boisguilbert through Cantillon, Quesnai, and Adam Smith to the 'classical' political economy of Malthus, Ricardo, and J. S. Mill, has its origin in Augustinian theodicy.

Though Nicole was so highly regarded in England that John Locke translated three of his essays, Boisguilbert's work remained unknown. His path-breaking economic ideas were transmitted instead through Bernard Mandeville's notorious satire, The fable of the bees: or, private vices, public benefits ([1714-1728] 1988), which was placed on the Index Librorum Prohibitorum in 1744. Like the Jansenists, whose work he would certainly have known, Mandeville assumed that self-love is evil; like them he argued that the "Publick Benefits" of market exchange are driven by this "Private Vice". The multifarious economic activities of modern society arise and can only arise in a gradual, unplanned, accidental, piecemeal fashion in response to the incentives for individual self-regarding action created by others' needs, wants, and desires. But his work appeared to be a crude parody and was reviled as blasphemous by the godly and respectable.

The reason for this adverse response was that if self-love really is a 'vice' then we have yet another nasty case of the problem of evil. Why does God allow (or worse, 'design') a world in which good things necessary for human life and happiness require moral evil for their production? The crucial question of course is the moral and theological standing of self-love. The Jansenists were ultra-Augustinian in regarding it as an 'evil passion', for St Augustine himself had acknowledged that God cannot be understood to have ruled out, or even to have frowned upon, self-love. Indeed, He commands it: 
Iam vero quia duo praecipua, hoc est dilectionem Dei et dilectionem proximi, docet magister Deus, in quibus tria invenit homo quae diligat, Deum, se ipsum et proximum, atque ille in se diligendo non errat qui Deum diligit [...] (Civ. Dei XIX, 14; italics added). ${ }^{1}$

We must therefore identify three senses or aspects of Caritas: Caritas $_{1}$ as love of God; Caritas $_{2}$ as love of neighbour; and Caritas $_{3}$ as love of self.

This theme was taken up and developed definitively by Joseph Butler, a convert from Dissent who eventually became Bishop of Durham and perhaps the most powerful theological mind of the eighteenth century. His fifteen Rolls Sermons (Butler [1726] 1969) were preached in the immediate aftermath of the public outcry aroused by the 1723 edition of the Fable (Waterman 1997, 240-241). As against the influential doctrine of Lord Shaftesbury's Characteristicks (1711), Butler showed that the ends of private good and public good "do indeed perfectly coincide"; that "self-love is one chief security of our right behaviour towards society"; that under Providence much unintended social good is produced by self-regarding actions; and that "there is seldom any inconsistency between what is called our duty and what is called interest" (Butler 1969, 32, 36, 37-38, 67). Sermons XI and XII, 'On the Love of our Neighbour' (164-202), recognize that Caritas ${ }_{3}$-love of selfis not merely permissible for the faithful but is actually a duty commanded by Christ himself.

Jansenist theodicy rectified by Anglican apologetic cleared the way for the development by Anglophone Christians of Boisguilbert's pioneering economic insights. The first was the Dean of Gloucester, the Reverend Josiah Tucker (1713-1799), who had been Butler's chaplain when the latter was Bishop of Bristol. In Elements of commerce (Tucker [1755] 1993, 58) he explains how "SELF-LOVE, the great Mover of created Beings, determines each Individual to aspire after these social Goods, and to use the most probable Means of obtaining them"; for

the same good Being who formed the religious System, formed also the commercial, and the End of both, as designed by Providence, is no other than this, That private Interest should coincide with public,

\footnotetext{
${ }^{1}$ Translation (Everyman edition): "God, our good master, teaching us in the two great commandments (the love of him and the love of our neighbours), to love three things: God, our neighbour and ourselves, and seeing that he that loves God offends not in loving himself $[\ldots] "$.
} 
self with social, and the present with future Happiness (Tucker [1757] 1993, 73).

All the ingredients were now to hand for what was to become, two decades later, the central message of The wealth of nations:

let the Legislature but take Care not to make bad Laws, and then as to good ones, they will make themselves: That is, the Self-Love and Self-Interest of each Individual will prompt him to seek such Ways of Gain, Trades and Occupations of Life, as by serving himself, will promote the public Welfare at the same Time (Tucker ([1757] 1993, 48).

Adam Smith acquired Tucker's writings for his own library (Mizuta 1996), and would also have known of Tucker and his ideas from his friends David Hume and Lord Kames. By the third quarter of the eighteenth century, English-speaking Christians had assimilated and domesticated a theological rationale of individual private interest in economic affairs that is now part of the air we breathe. Samuel Johnson, oracle of Tory high-church piety summarised it memorably: "There are few ways in which a man can be more innocently employed than in getting money" (Boswell [1791] 1960, 597).

\section{CONCLUDING REMARKS}

Caritas in Veritate is long, diffuse, and wide-ranging. I have deliberately ignored some of its most important ideas, such as those of development $(C V, 11,13-15,17-19,21,29,52,76,79)$, the common good $(C V, 7,21$, $36,41,57)$, and justice $(C V, 6,35,36,54,78)$. It correctly warns against rights talk and insists on the moral priority of duty ( $C V, 43)$; and correctly affirms that "Man is not a lost atom in a random universe: he is God's creature, whom God chose to endow with an immortal soul and whom he has always loved" $(C V, 29)$. More controversially it asserts that "on this earth there is room for everyone" $(C V, 50)$, and reiterates the teaching of Humanae Vitae-which rather surprisingly it supposes to be "without any direct link to social doctrine" $(C V, 15)$. Each of these neglected themes would require an article at least as long as this one to do it justice.

I have focussed narrowly on the relation between economics and theology in this encyclical, and the preceding Centesimus Annus, because I believe that in so doing we may discover the conceptual core of papal social doctrine, and thereby throw some light on the 
divergence-and partial isolation-of that doctrine from the mainstream of modern economic and social thinking. In particular I have tried to show that this divergence is not at all a consequence of the fact that whereas papal social doctrine is theologically informed, the mainstream is merely 'secular'. For though modern social theory, like all science, is indeed 'secular' in its method, its intellectual history reveals the formative role of a Christian theology based on exactly the same set of theological concepts as papal social doctrine. Divergence has come, rather, from the differing use made of that common theological material. Some of this can be explained by the growing intellectual estrangement of the Roman Church from the main currents of European thought in the eighteenth and early nineteenth centuries.

The so-called 'Enlightenment' in eighteenth-century France was anti-clerical and sometimes anti-Christian. An attack on 'superstition', identified with the doctrine of transubstantiation, was central (Waterman 2004, chapter 2). It was therefore difficult if not impossible for Catholic thinkers, whether Gallican or Ultramontane, to join in 'the Enlightenment project'. There were no major Catholic philosophers after Nicolas Malebranche (1638-1715), and even his work was placed on the Index. The French Revolution, which carried the French (but not English) Enlightenment attack on Christianity to its furthest extent, swept away the ancien régime of Church-and-State in France and elsewhere. The papacy was humiliated and almost destroyed. Though the Papal States were returned in 1815 and papal religion once again tolerated throughout Europe, the Roman communion was never restored to its commanding position as the established Church of the West. Its property was plundered and its authority ignored. For seventy years the Curia licked its wounds and bewailed "the philosophy of this age", which it blamed for "progress, liberalism and modern civilization" (Waterman 1991). When Leo XIII revived the philosophy of an earlier age in 1879 he restored the possibility of intellectual respectability, but did nothing to reunite Roman Catholic thought with the main stream. Indeed the effect of compulsory Thomism may only have made it more sectarian.

Meanwhile 'the Enlightenment project' had flourished in England. From Newton (1642-1727) and Locke (1632-1704) to Paley (1743-1805) and Malthus (1766-1834), its intellectual leadership came almost entirely from Anglicans, who so far from being bound by the doctrine of Transubstantiation were actually obliged to repudiate it. The English 
Enlightenment was therefore "conservative, clerical and magisterial" (Jacob 1981; see also Pocock 1980; 1985). It was in England rather than France that the decisive theological work was done to demonstrate that the new economic ideas of competitive individualism and spontaneous order are consistent with traditional Christianity.

In principle there is no reason why Romanist theologians should not have availed themselves of this new work, even though generated by those outside their communion. For example the Defensio Fidei Nicaenae (1685) of the Anglican theologian George Bull (1634-1710, Bishop of St David's from 1705) was warmly commended by the great Bossuet and other French theologians, and his Judicium Ecclesiae Catholicae (1694) received a formal tribute of thanks from the Synod of St Germain in 1700. But by the middle of the eighteenth century the Roman Church had become inward-looking and defensive, perhaps especially in France. It remained on the defensive until the pontificate of Leo XIII, by which time it had virtually cut itself off from all outside intellectual influences.

But the world has changed since 1891. If only because all the Christian churches and institutions in the North Atlantic world are now a dwindling and embattled minority, intellectual and cultural differences between Roman Catholics and the rest seem less acute than formerly. Papal social doctrine, which has exhibited many a twist and turn over the past 120 years (Waterman 1982), could easily be made to accommodate the social-theoretic implications of theological material already in place: and thereby purge itself of incoherence.

\section{REFERENCES}

Papal Encyclicals:

Authorised English translations [Libreria Editrice Vaticana] of: Caritas in Veritate ( $\mathrm{CV}$ ), Centesimus Annus (CA), Humanae Vitae (HV), Populorum Progressio (PP), from: www.vatican.va/holy_father/ (accessed October 2013).

English translations of: Aeterni Patris (AP), Quadragesimo Anno (QA), Libertas Praestantissimus (LP), Rerum Novarum (RN). In The Papal Encyclicals, 5 vols. 1981, ed. Claudia Carlen. Wilmington (NC): McGrath Publishing Company.

Other References:

Augustine of Hippo, St. 1960 [c. 426]. De Civitate Dei Contra Paganos, with English translation, 7 vols., trans. W. C. Greene. Cambridge (MA): Harvard University Press; London: Heinemann.

Boisguilbert, Pierre le Pesant, Sieur de. 1966. Pierre de Boisguilbert ou la Naissance de l'Économie Politique (ed. anon.); vol. 1, Préface-Études Biographie-CorrespondanceBibliographies; vol. 2, CEvres Manuscrites et Imprimées. Paris: Institut National D’Études Démographiques. 
Boswell, James. 1960 [1791]. The life of Samuel Johnson, LL.D. London, New York, Toronto: Oxford University Press.

Butler, Joseph. 1969 [1726]. Fifteen sermons preached at the rolls chapel and a dissertation upon the nature of virtue, ed. W. R. Matthews. London: Bell.

Deane, Herbert A. 1963. The political and social ideas of St Augustine. New York and London: Columbia University Press.

Domat, Jean. 1828-1829 [1689]. Traité des lois, in CEvres Complètes, vol I. Paris: Firmin Didot.

Faccarello, Gilbert. 1999. The foundations of laissez-faire: the economics of Pierre de Boisguilbert. London: Routledge.

Ferguson, Adam. 1767. An essay on the history of civil society. London: Millar and Cadell.

Hayek. F. A. 1967. Studies in philosophy, politics, and economics. New York: Simon \& Schuster.

Hirschman, Albert O. 1981. The rise and decline of development economics. In Essays in trespassing: economics to politics and beyond. Cambridge: Cambridge University Press, 1-24.

Hume, David. 1994 [1752]. Political essays, ed. Knud Haakonssen. Cambridge: Cambridge University Press.

Jacob, Margaret C. 1981. The radical enlightenment: pantheists, freemasons, and republicans. London: Allen and Unwin.

Mandeville, Bernard. [1714-1728] 1988. The fable of the bees: or, private vices, public benefits, 2 vols., ed. F. B. Kaye. Oxford: Clarendon Press. 1924. Facsimile reprint by Liberty Fund. Indianapolis: Liberty Press.

Mill, John Stuart. 1874 [1963-1991]. Nature. In Three essays on religion, vol. X of Collected Works of John Stuart Mill. Toronto: University of Toronto Press.

Mizuta, Hiroshi. 1996. Adam Smith's library: a catalogue. Oxford: Oxford University Press.

Neuhaus, Richard. 1991. Review essay. National Review, 43 (11): S8-9.

Nicole, Pierre. 1670. De l'éducation d'un prince. Paris: Charles Savreux.

Novak, Michael. 1991. Review essay. National Review, 43 (11): S11-12.

Pocock, J. G. A. 1980. Post-puritan England and the problem of the Enlightenment. In Culture and politics from puritanism to the Enlightenment, ed. Perez Zagorin. Berkeley: University of California Press.

Pocock, J. G. A. 1985. Clergy and commerce: the conservative Enlightenment in England. In L'Eta dei Lumi: Studi Storici sul Settecento Europeo in Onore Franco Venturi, eds. R. Ajello, et al. Naples: Juvene.

Smith, Adam. [1776] 1976. An inquiry into the nature and causes of the wealth of nations, eds. R. H. Campbell, A. S. Skinner, and W. B. Todd. Oxford: Clarendon Press.

Starkey, Thomas. 1989 [1538]. A dialogue between Pole and Lupsett. Republished, ed. T. F. Mayer. London: Royal Historical Society [Camden Miscellany 4th series, vol. 37].

Temple, William. 1976 [1942]. Christianity and social order. London: SPCK.

Tucker, Josiah. 1993 [1753-65]. The collected works of Josiah Tucker. London: Routledge/Thoemmes.

Waterman, A. M. C. 1982. Property rights in John Locke and in Christian social teaching. Review of Social Economy, 40 (2): 97-115. 
Waterman, A. M. C. 1991. The intellectual context of Rerum Novarum. Review of Social Economy, 49 (4): 465-482.

Waterman, A. M. C. 1999. Market social order and Christian organicism in Centesimus Annus. Journal of Markets and Morality, 2 (2): 220-233.

Waterman, A. M. C. 2003a. Romantic political economy: Donald Winch and David Levy on Victorian literature and economics. Journal of the History of Economic Thought, 25 (1): 91-102.

Waterman, A. M. C. 2003b. Economics, love and family values: Nancy Folbre and Jennifer Roback Morse on the invisible heart. The Independent Review, 7 (3): 443-453.

Waterman, A. M. C. 2004. Political economy and Christian theology since the Enlightenment: essays in intellectual history. New York: Palgrave Macmillan.

Anthony M. C. Waterman is professor emeritus of economics at University of Manitoba, and Fellow at St John's College, Winnipeg. His research focuses on various aspects of the relation of economic theory to Christian theology, and the related study of eighteenth and nineteenth-century intellectual history. His work on Christian political economy in Britain, c. 1798-1834, led him to his recent and current studies of Papal social doctrine.

Contact Email: <watermn@cc.umanitoba.ca $>$

Website: <http://amcwaterman.com> 